\title{
The State-of-the Art of the Borehole Disposal Concept for High Level Radioactive Waste
}

\section{고준위방사성폐기물의 시추공 처분 개념 연구 현황}

\author{
Sung-Hoon Ji1), Yong-Kwon Koh and Jong-Won Choi \\ Korea Atomic Energy Research Institute, 989-111 Daedeok-Daero, Yuseong-Gu, Daejeon \\ 지성훈1), 고용권, 최종원 \\ 한국원자력연구원, 대전시 유성구 대덕대로 989번길 111
}

(Received January 31, 2012 / Received March 09, 2012 / Approved March 09, 2012)

\begin{abstract}
As an alternative of the high-level radioactive waste disposal in the subsurface repository, a deep borehole disposal is reviewed by several nuclear advanced countries. In this study, the state of the art on the borehole disposal researches was reviewed, and the possibility of borehole disposal in Korean peninsula was discussed. In the deep borehole disposal concept radioactive waste is disposed at the section of $3-5 \mathrm{~km}$ depth in a deep borehole, and it has known that it has advantages in performance and cost due to the layered structure of deep groundwater and small surface disposal facility. The results show that it is necessary to acquisite data on deep geologic conditions of Korean peninsula, and to research the engineering barrier system, numerical modeling tools and disposal techniques for deep borehole disposal..
\end{abstract}

Key words : High-level waste, Borehole disposal, State of the art

\section{요 약}

고준위폐기물 처분과 관련하여, 최근 저장소 형태의 처분장 개념에 대한 대안으로 검토되고 있는 시추 공 처분 개념에 대한 연구 현황을 정리하고 시추공 처분 개념의 국내 적용 가능성과 필요한 연구 항목에 대해 논의하였다. 현재 미국과 스웨덴을 중심으로 논의된 시추공 처분 개념은 심부시추공을 설치하여 지 하 $3-5 \mathrm{~km}$ 구간에 고준위폐기물을 처분하는 것을 의미하며, 현재까지의 연구 결과에 의하면 이 처분 개 념은 심부지하수의 층상구조, 작은 규모의 지표시설 등으로 인해 처분 및 비용 효율이 클 것으로 예상된 다. 이에 반해 국내에는 축적된 심부 지질 자료가 없어 적용 가능성에 대한 논의할 여지가 없다. 이에 저 장소 형태의 처분장 개념에 대한 대안으로 시추공 처분 개념을 검토하기 위해서는 향후 심지층 자료 확 보, 공학적 방벽 연구, 수치모의모델 개발, 처분 기술 개발 등의 연구가 필요하다.

중심단어 : 고준위폐기물, 시추공 처분, 연구 현황

1) Corresponding Author. E-mail : shji $@$ kaeri.re.kr 


\section{I. 서 론}

지하 깊은 곳에 방사성폐기물을 처분하게 되면 방사성폐기 물에 대한 생물권과의 격리 측면에서 몇 가지 이점이 있다. 먼저 방사성폐기물과 생물권과의 물리적인 거리가 멀어지게 된다. 이에 따라 혹 처분지점으로부터 방사성 핵종이 유출되 었다 하더라도 생물권에 도달할 때에는 자연붕괴에 의해 낮 은 방사선량을 갖는 형태로 도달할 가능성이 높아진다. 두 번 째, 지하 깊은 곳의 지질매체는 투수성이 낮을 가능성이 높 다. 방사성폐기물을 지하에 처분하게 되면 유출된 핵종은 주 로 지하수를 따라 이동하여 생물권으로 노출되게 된다. 처분 위치의 지질매체가 낮은 투수성을 갖는다면 주변 지하수의 유동속도가 매우 느릴 것이며 이에 유출된 핵종 역시 느리게 이동하게 된다. 이에 역시 유출된 핵종이 낮은 방사선량을 가 지고 생물권에 도달할 확률이 높다. 세 번째, 지하 깊은 곳의 지하수는 지표로 올라올 가능성이 적다. 기존의 연구에 의하 면 북미대륙과 유럽의 경우 지하 $1 \mathrm{~km}$ 이하에는 염도가 매우 높은 염지하수(saline groundwater)가 존재하며 이에 염지하 수가 존재하는 곳에 방사성폐기물을 처분하면 밀도가 높은 염지하수가 지표로 이동하지 않아 생물권과의 격리가 더 확 실해지게 된다. 마지막으로 지화학조건이 핵종의 이동을 제 한할 가능성이 높다. 지하 깊은 곳은 지화학적으로 환원조건 일 확률이 높으며, 환원조건에서 대부분의 핵종은 지하수로 의 용해도가 매우 낮아 지하수를 따라 이동할 가능성이 낮다. 그리고 이온 강도가 매우 높은 염지하수에서는 핵종이 흡착 된 콜로이드의 생성과 이동이 제한된다.

기존의 토목 굴착 기술을 이용하여 지하 깊은 곳에 저장소 형태의 처분장을 건설하는 것에는 기술적 문제와 비용으로 인해 그 깊이에 한계가 있어 현재 지하 $1000 \mathrm{~m}$ 까지 가능하다 고 알려져 있다. 예를 들어, 현재 가장 깊은 곳에 있는 채굴갱 은 남아프리카에 있는 금광으로 지하 $3000 \mathrm{~m}$ 에 위치하고 있 으나 그 안정성에 있어 매우 심각한 문제를 갖고 있다. 이에 비해 시추 기술은 석유 개발 및 연구 시추와 더불어 매우 발 달하여 왔으며, 이에 연구를 위한 초고심도 시추공의 경우 독 일의 Rhine Graben에 $9000 \mathrm{~m}$ 의 시추공이 설치되어 있고, 석 유 시추공은 지하 $10 \mathrm{~km}$ 이하에도 설치할 수 있게 되었다. 이 에 따라 고심도 시추공에 방사성폐기물을 처분하는 시추공 처분에 대한 관심이 높아지게 되었다 [1].

방사성폐기물의 시추공 처분 개념은 주로 처분할 방사성폐 기물의 양이 매우 적은 몇몇 국가에 의해 연구되어 왔다. 이 들 나라에서는 소량의 폐밀봉선원을 장기저장하기 위해 시추 공 처분 개념을 고려하고 있으며, 이에 IAEA는 폐밀봉선원의
시추공 처분에 대한 기술보고서를 발간하여 그 처분 가이드 라인을 제시하였다 [2]. 폐밀봉선원의 시추공 처분에 대한 안 전성평가방법은 현재 개발 중이며 [3], 실제 시추공 처분을 시 행하고 있는 나라는 없다. 이와 별개로 처분장 모암을 녹이거 나 부분적으로 녹일 수 있는 열을 방출하는 고준위방사성폐 기물의 시추공 처분에 대해서는 미국, 스웨덴 등의 몇몇 국가 에 의해 연구되어 왔다. 이 처분 개념은 종래의 저장소 형태 의 처분장 개념에 비해 부차적으로 고려되어 왔으며, 활발히 연구되고 있지는 않다. 따라서 시추공 처분 개념이 그동안 많 이 연구되어온 저장소 형태의 처분장 개념과 비슷한 이해도 를 갖기 위해서는 많은 연구 비용이 소요될 것으로 예상된다. 그럼에도 불구하고, 시추공 처분은 저장소 형태의 처분장 개 념에 비해 처분 심도가 더 깊어 방사성폐기물을 좀 더 확실하 게 고립시킬 수 있고, 처분에 필요한 시설이 상대적으로 간단 해서 저장소 형태의 처분장 개념에 비해 경제적이라는 장점 이 있어, 최근 고준위방사성폐기물 또는 사용후핵연료의 처 분을 위한 저장소 형태의 처분장 개념의 대안으로 적극적으 로 검토되고 있다 [4][5][6]. 이에 본 연구에서는 고준위방사성 폐기물 및 사용후핵연료의 처분을 위해 그동안 연구되어 온 시추공 처분 개념에 대해 검토하고 국내 적용의 가능성에 대 해 논해보고자 한다.

\section{II. 시추공 처분 개념}

시추공 처분 개념은 지표에 비교적 작은 직경의 공학적 시 설을 갖춘 시추공을 설치한 후 그 안에 고체상 또는 액체성 방사성폐기물을 처분하는 것이다. 시추공의 깊이는 처분 대 상 물질에 따라 달라서 수 $\mathrm{m}$ 에서 수 $\mathrm{km}$ 까지 다양하며, 시추공 의 직경 역시 수십 $\mathrm{cm}$ 에서 수 $\mathrm{m}$ 까지 다양하게 고려되고 있다. Fig. $1 \mathrm{a}$ 는 미국의 시추공 처분 개요도이다. 고체 형태의 방사 성폐기물은 심도 $3-5 \mathrm{~km}$ 위치의 결정질 기반암에 처분되고 상부 퇴적층 구간에는 플러그와 뒷채움재가 채워진다. 이 때 결정질 기반암은 주로 화강암이다. 처분시설은 Fig. 1a과 같 이 단일 시추공으로 구성할 수도 있고 여러 개의 시추공으로 구성될 수도 있다. 이 때 시추공 사이의 거리는 처분된 폐기 물에서 발생하는 열이 다른 시추공에 영향을 미치지 않도록 약 $200 \mathrm{~m}$ 이상 떨어뜨려 설치하며, 이 거리는 Yucca Mountain 처분성능평가에서와 마찬가지로 25년 된 PWR(Pressurized Water Reactor) 핵연료집합체를 처분하였 을 때 시추공 처분환경에서의 열전도 모델링을 통해 설정된 것이다 [5]. Fig. 1b는 미국의 상세한 시추공 설계개념을 보여 준다. 약 $40.6 \sim 121.9 \mathrm{~cm}$ 의 직경을 갖는 시추공에 시추공 유 
지를 위해 깊이별로 다른 재질의 케이싱을 복합적으로 설치 한다. 방사성폐기물 캐니스터를 시추공에 처분하고 캐니스터 를 벤토나이트 슬러리로 둘러싼 후 그 위에 다져진 벤토나이 트를 $1 \mathrm{~m}$ 두께로 쌓는 과정을 심도 3 $5 \mathrm{~km}$ 의 처분 구간이 다 채워질 때까지 반복한다. 처분 구간이 채워지게 되면 그 구간 을 플러그나 팩커 등의 방벽으로 막고 그 위를 벤토나이트와 아스팔트, 콘크리트 등으로 봉한다. 서술한 처분시추공과 공 학적 방벽의 개념은 확정된 것이 아니고 향후 타당성 조사 등 을 통해 수정될 예정이다.

Fig. 2b는 고준위방사성폐기물 처분을 위해 스웨덴에서 제 안한 처분시추공의 상세 설계 개념이다. 시추공은 $60 \sim 80 \mathrm{~cm}$

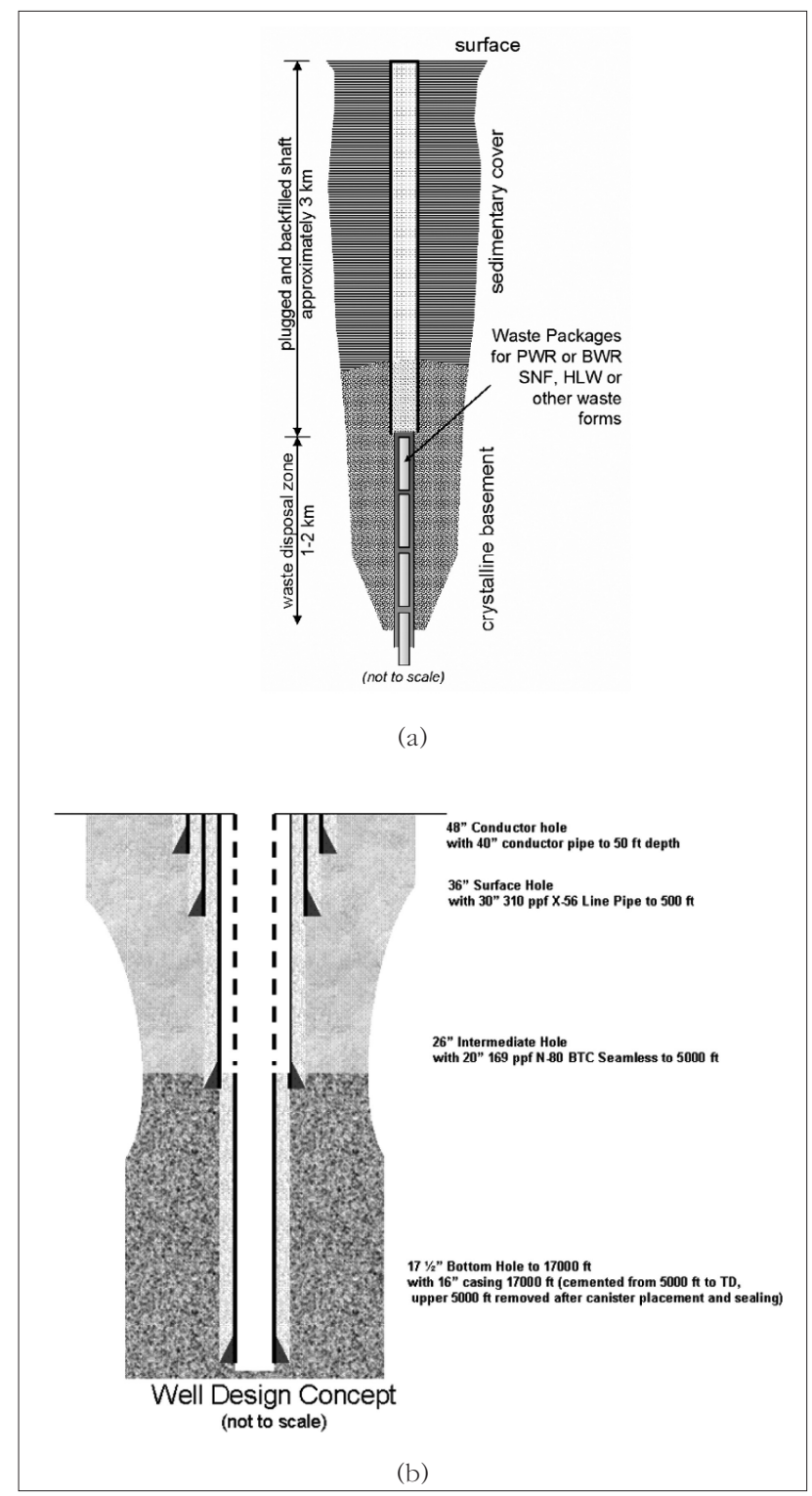

Fig. 1. (a) Schematic of the borehole disposal concept of U.S.; and (b) deep borehole design concept [5].
의 직경을 갖도록 굴착하며, $50 \mathrm{~cm}$ 직경의 캐니스터를 처분한 후 미국의 설계 개념과 비슷하게 그 주위를 벤토나이트로 둘 러싸고 캐니스터 사이에 벤토나이트를 넣어 고립시킨다. 그 리고 처분구간 외 상부 구간은 벤토나이트와 아스팔트, 콘크 리트로 봉한다. Fig. 2a는 단일 시추공 처분 시스템 외에 스웨

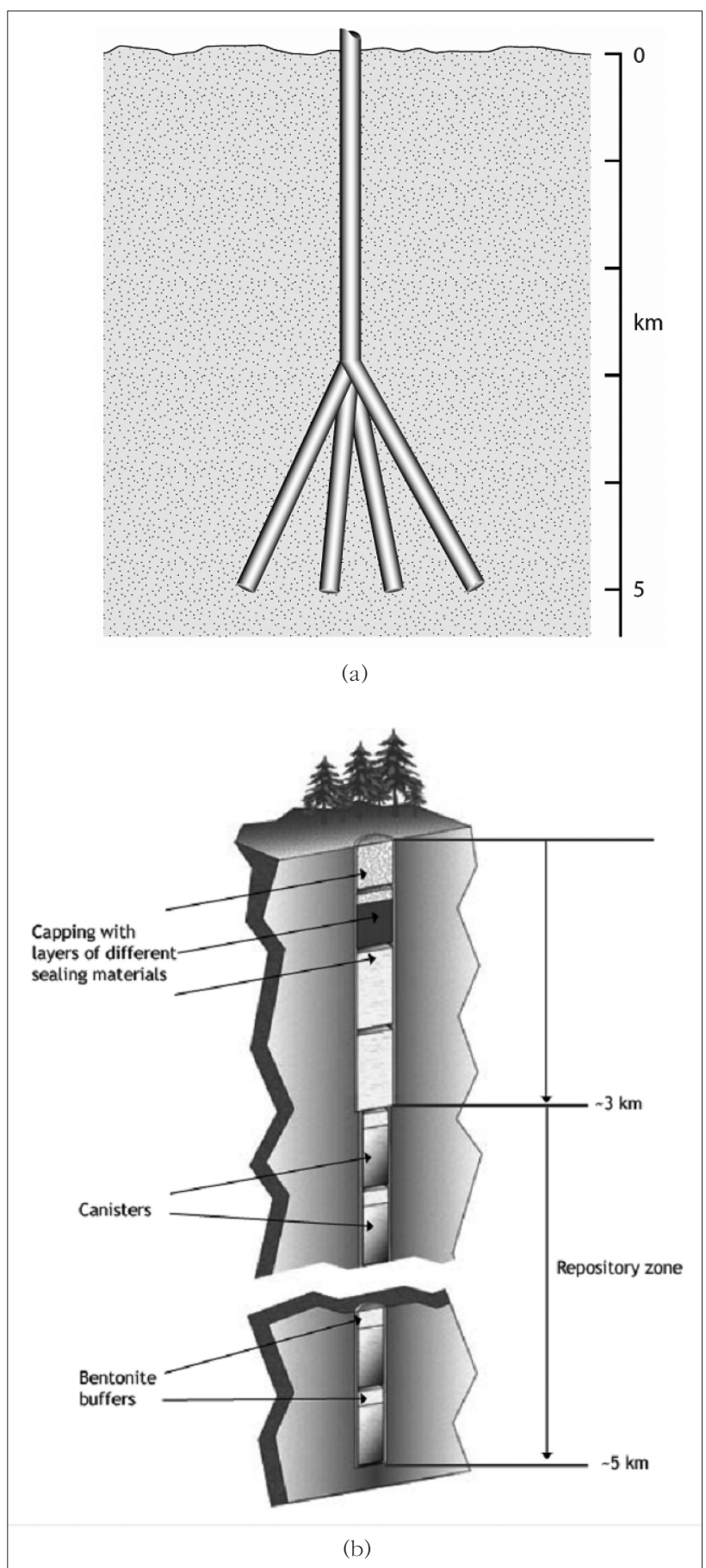

Fig. 2. (a)Advanced borehole disposal system; and (b) borehole design concept suggested by Sweden [6] 
덴에서 제안한 시추공 처분 시스템으로, 시추 공법의 발달로 인해 그림과 같이 복잡한 시스템도 고려할 수 있게 되었다. 이와 같이 시추공 처분 시스템은 지표 시설이 저장소 형태의 처분장 개념에 비해 매우 작아서 상대적으로 인간 침입의 가 능성이 적다는 장점이 있는 대신, 길이 $5 \mathrm{~km}$ 이상의 시추공을 설치해야 하고 지하 깊은 곳의 환경을 조사/해석/모델링해야 하므로 관련 기술에 대한 많은 연구가 필요하다.

\section{III. 시추공 처분 환경}

시추공 처분 개념의 적용 가능성 및 안전성을 논하기 위 해서는 무엇보다 처분 시스템이 위치할 처분 환경을 검토하 는 것이 필요하다. 이와 관련하여 미국과 스웨덴은 시추공 처분 시스템이 위치할 처분 환경에 대해 고려하여 왔으며 본 장에서는 상기 두 국가가 검토한 시추공 처분 환경에 대 해 정리/분석하고자 한다.

\section{가. 미국}

최근 미국은 시추공 처분 환경에 대해 가상의 처분 환경 을 가정하고 예비 안전성 평가를 수행하여 그 가능성을 평 가하였다 [5]. 그 결과를 대략적으로 살펴보면, 심부시추공 에 사용후핵연료를 처분하였을 때 핵종이 시추공이나 시추 공 주변을 떠날 가능성이 거의 없는 것으로 나타났고 대부 분의 핵종이 열역학적으로 안정적이어서 지하수 등에 용해 되어 인근 모암으로 이동할 확률 역시 적은 것으로 나타났 다. 구체적으로 폐기물을 시추공에 처분한 후부터 600년까 지는 최대 $0.7 \mathrm{~m} / \mathrm{yr}$ 까지 수직적인 지하수 흐름이 있지만 그 외 기간에는 수직적인 지하수 흐름이 없어 처분 구간에서의 수직적인 유체 이동은 $100 \mathrm{~m}$ 를 초과하지 않았고, 이류에 의 한 이동 없이 확산 현상만으로는 100 만년 동안 핵종이 $200 \mathrm{~m}$ 이상 이동할 수 없었다. 이에 지하수를 따라 인간 생 활권에 도달하는 핵종은 ${ }^{129} \mathrm{I}$ 하나에 국한되고 이마저도 그 양이 매우 작아 현재 기준치보다 10 차수 낮은 것으로 예측 되었다.

예비 안전성 평가를 위해 가정한 시추공 처분 환경은 다 음과 같다. Juhlin and Sandstedt [7]에 의해 정리된 5개의 심부시추공 조사 결과에 따르면, $4 \mathrm{~km}$ 이하에 위치한 지질 매체는 0.001 보다 작은 공극율과 $10^{-16}-10^{-20} \mathrm{~m}^{2}$ 의 투수도를 갖고, 깊이에 따른 지하수의 온도 차이에 의해 발생하는 대 류 현상이 일정 구간 내에서 안정적이며 염도가 $150 \mathrm{~g} / \mathrm{L}$ 이 상으로 매우 높았다. 또한 지질매체의 대부분이 화강암과 같은 결정질암으로 암체 자체가 크고 대체로 균질하며 높은
역학적 강도를 지닌 것으로 조사되었으며 암반 내 지하수의 유동로가 될 수 있는 단열도 상부의 두꺼운 지질층으로 인 해 대부분 닫혀 있는 것으로 나타났다. 이를 바탕으로, 수행 된 예비 안전성 평가에서는 Table 1과 같이 지질매체 및 시 추공의 물리적 특성을 가정하였다. 기반암은 화강암으로 가 정하였고 뒷채움재는 벤토나이트를 사용한 것으로 가정하 였다. 시추공에 처분된 폐기물은 25년된 PWR 핵연료집합체 로, 시간에 따라 열을 방출하며 일부가 철로 구성되어 열전 도도가 높은 것으로 가정하였다. 처분 위치에서 염도는 $~ 2$ - $3 \mathrm{M} / \mathrm{L}, \mathrm{pH}$ 는 8 - 9, Eh는 약 $-300 \mathrm{mV}$, 온도는 $100^{\circ} \mathrm{C}$ 이상일 것으로 예상된다 [8]. 이 중 처분 환경의 온도를 $200^{\circ} \mathrm{C}, \mathrm{pH}$ 를 $8.5, \mathrm{Eh}$ 를 $-300 \mathrm{mV}, 2 \mathrm{M}$ 의 $\mathrm{NaCl}$ 용액을 가정하고 여러 핵 종의 용해도를 열역학자료와 지구화학모의모델(PHREEQC 2.12.03)로 예측하였다(Table 2). 그리고 각 핵종의 흡착에 대한 분배계수는 McKinley and Scholtis [9]이 개략적으로 계산하여 제안한 값과 같다고 가정하였다(Table 3).

시추공 처분 개념의 예비 성능 평가를 위해 선택한 시나 리오는 Yucca Mountain 부지와 WIPP 부지에 적용된 것과 비슷한 것을 선택하여, 총 374개의 FEPs(Features, Events, and Processes)를 선택하였다. 그리고, 이 FEPs를 평가하기 위해 적용한 가정들은 Yucca Mountain 부지에 대한 성능

Table 1. Physical properties of the geologic medium and disposal borehole assumed for preliminary safety assessment [5].

\begin{tabular}{|c|c|c|c|c|}
\hline $\begin{array}{c}\text { Physical } \\
\text { properties }\end{array}$ & Bedrock & $\begin{array}{c}\text { Disturbed } \\
\text { bedrock }\end{array}$ & $\begin{array}{c}\text { Borehole sealed with } \\
\text { backfill material }\end{array}$ & $\begin{array}{c}\text { Borehole filled } \\
\text { with waste }\end{array}$ \\
\hline Permeability [m²] & $10^{-19}$ & $10^{-16}$ & $10^{-16}$ & $10^{-16}$ \\
\hline Density [kg/m] & 2750 & 2750 & 2750 & 2750 \\
\hline $\begin{array}{c}\text { Specific heat } \\
{\left[\mathrm{MJ} / \mathrm{kg}-{ }^{-} \mathrm{K}\right]}\end{array}$ & 790 & 790 & 760 & 760 \\
\hline $\begin{array}{c}\text { Heat } \\
\text { conductivity } \\
{\left[\mathrm{W} / \mathrm{m}-{ }^{\circ} \mathrm{K}\right]}\end{array}$ & 3.0 & 3.0 & 0.8 & 46.0 \\
\hline Porosity & 0.01 & 0.01 & 0.35 & 0.0001 \\
\hline
\end{tabular}

Table 2. Solubilities of several nuclides at the borehole disposal condition [5].

\begin{tabular}{|c|c|c|c|}
\hline Nuclide & $\begin{array}{c}\text { Solubility- } \\
\text { limiting phase }\end{array}$ & $\begin{array}{c}\text { Solubility } \\
\text { (moles/L) }\end{array}$ & Note \\
\hline $\mathrm{Am}$ & $\mathrm{Am}_{2} \mathrm{O}_{3}$ & $1.0 \times 10^{-9}$ & $\begin{array}{c}\mathrm{AmOH}\left(\mathrm{CO}_{3}\right) \text { controls the solubility } \\
\text { of Am if there is a carbonate }\end{array}$ \\
\hline $\mathrm{Ac}$ & $\mathrm{Ac}_{2} \mathrm{O}_{3}$ & $1.0 \times 10^{-9}$ & $\begin{array}{c}\text { The solubility of Ac is estimated with } \\
\text { Am that is chemically close to } \mathrm{Ac}\end{array}$ \\
\hline $\mathrm{C}$ & $*$ & $*$ & No solubility-limiting phase \\
\hline $\mathrm{Cm}$ & $\mathrm{Cm}_{2} \mathrm{O}_{3}$ & $1.0 \times 10^{-9}$ & $\begin{array}{c}\text { The solubility of Cm is estimated } \\
\text { with Am that is chemically } \\
\text { close to Cm }\end{array}$ \\
\hline $\mathrm{Cs}$ & $*$ & $*$ & No solubility-limiting phase \\
\hline $\mathrm{I}$ & $\mathrm{Metal}$ iodides? & $*$ & \\
\hline $\mathrm{Np}$ & $\mathrm{NpO}_{2}$ & $1.1 \times 10^{-18}$ & \\
\hline $\mathrm{Pa}$ & $\mathrm{PaO}_{2}$ & $1.1 \times 10^{-18}$ & $\begin{array}{c}\text { The solubility of Pa is estimated with } \\
\text { Np that is chemically close to Pa }\end{array}$ \\
\hline $\mathrm{Pu}$ & $\mathrm{PuO}_{2}$ & $9.1 \times 10^{-12}$ & \\
\hline $\mathrm{Ra}$ & $\mathrm{RaSO}_{4}$ & $*$ & \\
\hline $\mathrm{Sr}$ & $\mathrm{SrCO}_{3}, \mathrm{SrOO}_{4} ?$ & $*$ & \\
\hline $\mathrm{Tc}$ & $\mathrm{TcO}_{2}$ & $4.3 \times 10^{-38}$ & \\
\hline $\mathrm{Th}$ & $\mathrm{ThO}_{2}$ & $6.0 \times 10^{-15}$ & \\
\hline $\mathrm{U}$ & $\mathrm{UO}_{2}$ & $1.0 \times 10^{-8}$ & \\
\hline
\end{tabular}


Table 3. Distribution coefficients of several nuclides at the borehole disposal condition [9].

\begin{tabular}{|c|c|c|c|}
\hline Nuclide & $\begin{array}{c}\text { Kd in the bedrock } \\
(\mathrm{ml} / \mathrm{g})\end{array}$ & $\begin{array}{c}\text { Kd in the upper } \\
\text { sedimentary layer }(\mathrm{ml} / \mathrm{g})\end{array}$ & $\begin{array}{c}\text { Kd in the bentonite } \\
(\mathrm{ml} / \mathrm{g})\end{array}$ \\
\hline Am, $\mathrm{Ac}, \mathrm{Cm}$ & $50-5000$ & $100-100000$ & $300-29400$ \\
\hline $\mathrm{C}$ & $0-6$ & $0-2000$ & 5 \\
\hline $\mathrm{Cs}$ & $50-400$ & $10-10000$ & $120-1000$ \\
\hline $\mathrm{Np}, \mathrm{Pa}$ & $10-5000$ & $10-1000$ & $30-1000$ \\
\hline $\mathrm{Pu}$ & $10-5000$ & $300-100000$ & $150-16800$ \\
\hline $\mathrm{Ra}$ & $4-30$ & $5-3000$ & $50-3000$ \\
\hline $\mathrm{Sr}$ & $4-30$ & $5-3000$ & $50-3000$ \\
\hline $\mathrm{Tc}$ & $0-250$ & $0-1000$ & $0-250$ \\
\hline $\mathrm{Th}$ & $30-5000$ & $800-60000$ & $63-23500$ \\
\hline $\mathrm{U}$ & $4-5000$ & $20-1700$ & $90-1000$ \\
\hline $\mathrm{I}$ & $0-1$ & $0-100$ & $0-13$ \\
\hline
\end{tabular}

평가에 적용한 것과 같으며 다음과 같다 [5][17].

- 생물권으로의 노출은 시추공 주변의 오염된 지하수 관 정을 통해 이루어지며 이에 따라 불포화대를 통한 이동경로 는 없다. 그러나 경작, 관개, 목축, 식용수 등 오염된 관정수 를 통한 이동경로는 모두 고려한다.

- 폐기물 포장재나 폐기물 형태는 유체 흐름의 방벽이 되 지 않으며, 이에 따라 폐기물 포장재나 폐기물 형태의 방벽 효과와 관련된 모든 FEPs는 성능 평가에서 제외한다. 그러 나, 폐기물 포장재와 폐기물 형태의 화학적 효과는 반드시 고려한다.

- 폐기물이 처분된 처분구간의 시추공도 봉합재와 함께 공학적 방벽에 포함된다.

- 뒷채움재는 처분 구간 내 폐기물 용기 주변을 채우는 물 질이다.

- 핵종의 주요 이동 경로는 두 개로 하나는 공학적 방벽을 통한 이동이고 다른 하나는 주변 모암의 포화대를 통한 이 동이다. 이에 시추공을 통한 핵종 이동, 시추공 주변 교란된 모암을 통한 핵종 이동, 모암 내 지하수를 통한 핵종 이동을 고려하였다.

- 해군과 DOE의 사용후핵연료는 이 예비 성능 평가에서 제외한다.

- 폐기물의 회수성(retrievability)는 이 예비 성능 평가에 서 고려하지 않는다.

상기 기술한 시추공 처분 환경에 덧붙여 미국이 개략적으 로 예상한 시추공 처분을 위한 부지 크기와 처분 비용은 다 음과 같다. 미국 에너지부는 109,300MTHM(metric tons heavy metal)의 고준위폐기물과 사용후핵연료를 처분할 필 요가 있다고 예상하고 있다 [10]. 미국에서 고려 중인 시추 공 처분 개념에 따르면 각 심부시추공은 길이 $2 \mathrm{~km}$ 의 처분 구간을 가지며 이 처분구간에는 약 400 개의 수직 핵연료집 합체를 처분할 수 있다 [5]. 이에 70,000MTHM의 폐기물을
처분하기로 했었던 Yucca Moutain 처분장을 시추공 처분 개념으로 대체하기 위해서는 약 600개의 심부 시추공이 필 요하고, 나머지 39,300MTHM의 폐기물을 위해 약 350 개 이 상의 심부 시추공이 추가될 필요가 있는 것으로 예측된다. 그리고 이 시추공들의 간격을 시추공 처분 개념을 따라 $200 \mathrm{~m}$ 로 한다면, 시추공 처분을 위해 총 약 $30 \mathrm{~km} 2$ 의 부지 가 필요할 것으로 계산된다. 처분 비용과 관련하여서, 현재 $5 \mathrm{~km}$ 의 시추공을 설치하는데 미화 2천만달러 정도가 소요 되는 것으로 알려져 있으며, 이에 전체 109,300MTHM의 폐 기물을 처분하기 위해 950 개의 시추공을 설치한다면 시추 비용은 총 약 190 억달러가 소요될 것으로 예상된다. 다른 비용에 대해 개략적으로 계산해본다면 부지 특성화, 성능 평가, 허가 지원에 약 100 억달러, 처분 운영, 모니터링, 해 체에 약 200 억달러, 부수 비용에 약 120 억달러, 운송에 약 100 억달러가 예상되어, 총 710 억달러의 처분 비용이 예상 된다. 그러나 이 비용은 시추 비용이 점차 감소하고 있는 것 을 감안할 때 더 작아질 가능성이 있으며, 비단 이를 고려하 지 않더라도 Yucca Mountain 부지에 저장소 형태의 처분 장 개념을 도입하는 것보다는 훨씬 작은 비용이라 할 수 있 다 [5].

\section{나. 스웨덴}

현재 스웨덴에는 3 개의 부지에 심부 시추공이 설치되어 있으며, 이들 시추공에서의 조사 결과에 따르면 지하 $1.5 \mathrm{~km}$ 를 경계로 지압, 단열 시스템, 지하수의 화학 성분이 크게 변하는 것으로 나타났다. 이에 스웨덴은 시추공 처분 환경 을 위한 첫 번째 조건으로 처분 깊이는 지하 $1.5 \mathrm{~km}$ 이하로 하였다 [11]. 그리고 시추 비용과 밀도가 높은 염지하수에 의 한 지하수 흐름이 활발한 상부 대수층과 처분 구간의 연결 을 막아 줄 완충 효과를 생각하여 지하 $3 \sim 5 \mathrm{~km}$ 를 처분 깊이 로 고려하고 있다 [4]. 지금까지 시추공 처분을 위한 지하 3 $5 \mathrm{~km}$ 의 처분 구간에 대해 스웨덴이 조사한 결과는 다음과 같이 요약될 수 있다 [12].

지하 3 5 km의 처분 구간에서 지하수 및 가스의 수리전 도도는 $10^{-16} \mathrm{~m} / \mathrm{s}$ 이하로, 단열대 외에는 지하수나 가스가 잘 흐르지 않는다. 더구나 처분 구간에서 투수도가 작은 기반 암은 대부분 단열대로부터 떨어진 순상지 기반암으로, 처분 구간의 지질 매체에서 지하수가 빨리 흐를 가능성은 거의 없다 [12]. 그리고, 처분 구간의 지하수는 염도가 매우 높아 밀도가 낮은 상부 지하수와 매우 안정적인 층상 구조를 이 루고 있다. 처분 구간 지하수의 동위원소 특성과 매우 높은 가스 농도는 이 안정적인 층상 구조가 수백만년동안 지속되 
어 온 것을 말해주며, 이는 시추공에 처분될 폐기물이 지표 의 생물권과 철저히 고립될 확률이 매우 크다는 것을 보여 준다 [11]. 참고로 해안 지역의 염수와 담수의 층상 구조도 방사성폐기물의 고립에 효과적이라고 생각할 수 있겠으나, 해안 지역은 투수도가 비교적 크고 이에 따라 파도나 해류 의 영향을 받을 가능성이 있어 효과적이지만은 않다. 지구 화학적 환경과 관련하여, 처분 구간은 압력과 온도가 매우 높아 유출된 핵종이 흡착될 확률이 높다 [12]. 특별히 TC-99 와 Np-237과 같은 장반감기 핵종의 경우 처분 구간의 압력 과 온도 하에서 그 용해도가 매우 낮은 것으로 조사되어 역 시 유출된 핵종이 생물권과 완전히 고립될 가능성이 높다 [13]. 방사성폐기물은 방사성붕괴로 수천년동안 열을 발생시 킬 수 있으며, 이는 대류 현상을 야기하여 시추공에서 유출 된 핵종을 지표로 이동시킬 가능성이 있다. 스웨 덴은 이 가 능성을 차단하기 위해 열이 많이 발생하는 초기 15 50년 동안 고준위폐기물을 Oskarshamn 부지의 CLAB에 중간 저 장하는 것을 고려하고 있다. 더불어 폐기물의 밀도가 줄도 록 포장을 한다든지 시추공 내 완충지대의 부피를 늘려 발 생하는 열의 효과를 감소시키는 것도 고려하고 있으나, 이 는 처분에 필요한 시추공의 숫자를 늘려 처분 비용이 증가 할 가능성이 있다 [4]. 처분 구간의 압력과 온도 하에서도 미 생물이 존재할 수 있으며 미생물의 존재는 처분 환경의 지 화학적 조건을 바꿀 수 있다 [14]. 그러나 미생물이 처분 구 간에서의 핵종 거동에 어떤 영향을 미치는지 아직 연구된 바는 없다.

이들 조사 결과를 바탕으로 방사성폐기물의 시추공 처분 을 위해 스웨덴이 설정한 처분 조건은 다음과 같다 [4]. 먼저 처분 개념과 그 비용에 대해 정치적/사회적인 공감대가 형 성되어야 하며 시추공이 설치될 충분한 부지가 존재하여야 한다. 그리고 지하 $3 \sim 5 \mathrm{~km}$ 구간에 밀도에 인한, 매우 안정 적인 지하수 층상구조가 존재하여야 한다. 그리고 지하수 층상 구조의 교란없이 지하 $5 \mathrm{~km}$ 까지 정확하게 시추를 하고 그 깊이의 지질, 수리지질, 지구화학 조건을 조사/분석할 수 있는 기술이 확보되어야 하며, 역시 지하수 층상 구조의 교 란없이 폐기물을 처분하고 공학적 방벽을 설치할 수 있는지 확인되어야 한다.

전술한 시추공 처분 환경 및 조건에 덧붙여 스웨덴이 예 상한 처분 비용은 다음과 같다. 시추공 처분 개념 도입 시 필 요한 시추공은 20 40개이며, 많은 탐사공을 이용한 부지 결정 과정 후 처분장을 조성하는데 약 $10 \sim 15$ 년이 걸릴 것 으로 예상하였다 [11]. 그리고 시추공 하나를 설치하는데 약 4 천만SEK(미화 약 600백만달러)가 소요되어 시추공들을 설
치하는데에만 약 20 억SEK(미화 약 3억달러)가 소요될 것으 로 예상하였다 [15].

\section{IV. 결론 및 토의}

고준위폐기물 처분과 관련하여 저장소 형태의 처분장 개념 의 대안으로 떠오른 시추공 처분 개념에 대해 지금까지 검토 해온 결과를 미국과 스웨덴의 경우를 중심으로 정리하였다. 살펴본 바와 같이 시추공 처분 개념은 저장소 형태의 처분장 개념보다 더 깊은 지하 $3 \sim 5 \mathrm{~km}$ 에 폐기물을 처분하는 것으로 낮은 투수도, 높은 염도로 인한 지하수 층상 구조, 높은 온도 와 압력 그리고 염도에 의한 환원 지구화학 환경 등에 의해 폐 기물 처분의 성능에 상대적으로 이점이 있다. 그리고 지표 및 지하시설이 간단하여 비용 측면과 인간 침입 방지 측면에서도 효과적이다. 그러나 미국과 스웨덴의 조사 결과를 통해 설정 된 시추공 처분 환경은 소수의 심부 관정을 통해 조사된 결과 를 토대로 한 것으로 이를 바탕으로 시추공 처분 개념이 저장 소 형태의 처분장 개념보다 우월하다고 확언할 수는 없다. 이 에 저장소 형태의 처분장 개념에 대한 대안으로 시추공 처분 개념을 고려하기 위해서는 더 많은 심부 관정을 통한 처분 환 경의 특성화가 필요하다. 아울러 그동안 연구되어온 저장소 형태의 처분장 개념에 비해 처분 방법, 공학적 방벽의 구성, 천연 방벽의 불확실성 등에 대한 고려가 부족하여 실제 적용 을 위해서는 작은 규모의 현장 실험, 방벽의 성능을 평가하기 위한 수치 모델 개발 및 적용 등을 통한 많은 연구가 요구된 다.

우리나라는 현재 시추공 처분 개념과 관련하여 연구된 사례 가 없다. 심부 조사와 관련하여서, 우리나라에 가장 깊이 설치 된 장심도 시추공은 한국지질자원연구원에서 지열수 개발 관 련 연구를 위해 포항시 북구 일원에 설치한 심도 $2283 \mathrm{~m}$ 의 시 추공이다 [16]. 이 시추공을 이용한 조사 결과에 따르면 심도 $2265 \mathrm{~m}$ 까지는 퇴적암과 화산퇴적암이 층을 이루고 있으며 그 이하로 심성암인 화강섬록암이 존재하는 것으로 나타났다. 이 지역에는 단열도 많이 발달하여 지하 $1700 \mathrm{~m}$ 부근까지 단열대 가 존재하며, 가장 심도가 깊은 화강섬록암에는 엽리가 발달 한 것으로 나타났다. 이를 통해 이 지역은 비록 지하 $2 \mathrm{~km}$ 부 근이라도 그 투수도가 작지 않을 것이라 짐작할 수 있지만, 이 현장에서는 구간별로 수리시험이 수행되지 않아 그 값을 알 수 없다. 지하수 표본 채취는 지하 $1497 \mathrm{~m}$ 까지만 이루어져 그 심도에서 $\mathrm{pH}$ 는 $7.89, \mathrm{EC}$ 는 $20100 \mu \mathrm{s} / \mathrm{cm}$, 온도는 $65^{\circ} \mathrm{C}$ 로 측정 되었다. 그리고 연구 부지는 동해와 인접해 있어 해수의 영향 을 직간접적으로 받고 있는 것으로 조사되었다. 이에 따라 현 
재 국내에는 시추공 처분 개념의 적용 가능성에 대해 판단할 수 있는 자료가 없다.

이에 시추공 처분 개념의 국내 적용 가능성을 논하기 위해 서는 다음과 같은 선행 연구가 필요할 것으로 판단된다. 먼저 시추공 처분 개념의 처분 심도인 지하 $3 \sim 5 \mathrm{~km}$ 의 지질학적 환 경, 수리지질학적 환경, 지구화학적 환경을 조사하는 것이 필 요하다. 전술한 바와 같이 북미대륙과 유럽에는 오랫동안 지 질학적 사건을 겪지 않은 순상지가 존재하며, 이에 지하 깊은 곳에 투수성 단열대 등이 발달하지 않아 투수도가 낮다. 그리 고 지하수와 주변 광물이 오랜 시간동안 반응하면서 염도가 높은 염지하수를 형성하였다. 이에 반해 우리나라는 섭입대 (subduction zone) 인근에 위치하여 최근까지도 많은 지질학 적인 사건을 경험하였으며 산간 지역이 많아 미국, 스웨덴 등 의 심부 환경과 다른 환경을 갖고 있을 가능성이 있다. 이에 지하 $5 \mathrm{~km}$ 이상의 연구용 시추공을 몇몇 부지에 설치하여 그 심부 환경을 조사할 필요가 있다. 그리고, 시추공 처분 개념을 위한 공학적 방벽에 대한 연구가 필요하다. 현재 시추공 처분 개념에서의 공학적 방벽은 저장소 형태의 처분장 개념에서의 처분공을 위한 공학적 방벽과 거의 흡사하다. 그러나, 시추공 처분 개념에서는 시추공이 지표로부터 바로 착공되어, 시추공 자체가 핵종이 생물권으로 이동할 수 있는 직접적인 이동경로 가 될 가능성이 저장소 형태의 처분장 개념보다 훨씬 높다. 이 에 공학적 방벽의 구성 및 재료, 성능 등에 관한 연구가 필요 하다. 또, 안전성 평가를 위해 시추공 및 주변에서의 지하수와 핵종의 이동을 모의하기 위한 수치 모델의 개발이 필요하다. 현재 많이 사용되고 있는 수치 모델은 수리-열-역학적 변화를 연계하여 지하수와 핵종의 이동을 모의하는 모델로, 이는 현 저장소 형태의 처분 개념에서 지하수 이동에 대한 용질 농도 에 의한 영향이 나머지 수리, 열, 역학적 변화의 영향보다 작 기 때문이다. 그러나, 시추공 처분 개념의 경우 처분 환경에서 용질의 농도가 매우 높아 지하수 및 핵종의 이동에 이 용질의 농도가 큰 영향을 미칠 가능성이 높으며 이에 수리-용질농도열-역학적 변화를 연계하여 지하수와 핵종의 이동을 모의하는 수치 모델의 개발이 요구된다. 마지막으로, 심부 시추 기술, 시추공으로의 폐기물 적치 기술, 공학적 방벽 설치 기술 등에 관한 연구도 필요할 것이다.

\section{감사의 글}

본 연구는 과학기술부 원자력연구개발사업과 지식경제부 재원의 한국에너지기술평가원(KETEP, No. 201017102002D) 의 지원을 받아 수행하였습니다.

\section{References}

[1] NIREX, A Review of the Deep Borehole Disposal Concept for Radioactive Waste, Nirex report no. N/108, Oxfordshire, UK (2004).

[2] IAEA, Safety considerations in the disposal of disused sealed radioactive sources in borehole facilities, IAEA-TECDOC-1368, International Atomic Energy Agency (IAEA), Vienna, Austria (2003).

[3] IAEA, IAEA Safety report series: Generic postclosure safety assessment for borehole disposal of disused sealed sources (Draft 0.6 results), International Atomic Energy Agency (IAEA), Vienna, Austria (2007).

[4] K.-I. Åhäll, Final disposal of high-Level nuclear waste in very deep boreholes: An evaluation based on recent research of bedrock conditions at great depths, MKG Report 2, Swedish NGO Office of Nuclear Waste Review (MKG), Göteborg, Sweden (2006).

[5] P. V. Brady, B. W. Arnold, G. A. Freeze, P. N. Swift, S. J. Bauer, J. L. Kanney, R. P. Rechard and J. S. Stein, Deep borehole disposal of high-level radioactive waste, Sandia report SAND 2009-4401, Albuquerque, NM (2009).

[6] N. Chapman and F.G.F. Gibb, "A truly final waste management solutions: Is very deep borehole disposal a realistic option for high-level waste or fissile materials?", Radwaste Solutions, 10, pp. 2637 (2003).

[7] C. Juhlin and H. Sandstedt, Storage of nuclear waste in very deep boreholes: Feasibility study and assessment of economic potential. Part I: Geological consideration. Part II: Overall facility plan and cost analysis, TR 89-39, SKB, Stockholm, Sweden (1989).

[8] V. K. Anderson, An evaluation of the feasibility of disposal of nuclear waste in very deep boreholes, Dept. of Nuclear Engineering, Cambridge, MA (2004).

[9] I. G. Mckinley and A. Scholtis, "A comparison of radionuclide sorption databases used in recent 
performance assessments", J. Contam. Hydrol. 13, pp. 347-363 (1993).

[10] DOE, Anaysis of the total system life circle cost of the civilian radioactive waste management program, Fiscal year 2007, DOE/RW-0591, Washington D.C. (2008).

[11] C. Juhlin, T. Wallroth, J. Smellie, T. Eliasson, C. Ljunggren, B. Leijon and J. Beswick, The very deep borehole concept: Geoscientific appraisal of conditions at great depth, TR 98-05, SKB, Stockholm, Sweden (1998).

[12] J. Smellie, Recent geoscientific information relating to deep crustal studies, R-04-09, SKB, Stockholm, Sweden (2004).

[13] MIT, The future of nuclear power: An interdisciplinary MIT study, Massachusetts Institute of Technology (MIT), Boston, MA (2003).

[14] W. Sand, "Microbial life in geothermal waters", Geothermics, 32, pp. 645-667 (2003).

[15] T. Harrison, Very deep borehole. Deutags opinion on boring, canister emplacement and retrievability, R-00-35, SKB, Stockholm, Sweden (2000).

[16] KIGAM(Korea Institute of Geoscience and Mineral Resources), Development of deep, low-enthalpy geothermal energy, OAA2003001-2006, KIGAM, Daejeon (2006).

[17] S.H. Lee and Y.S. Hwang, "Technical standards on the safety assessment of a HLW repository in other countries", Journal of the Korean Radioactive Waste Society, 7, pp. 183-190 (2009). 